\title{
Optimizing the rate of phosphorus to enhance grain yield and quality in two Camelina sativa (L.) crantz accessions
}

\section{Otimizando a taxa de fósforo para aumentar o rendimento e a qualidade dos grãos em dois acessos de Camelina sativa (L.) crantz}

\author{
Muhammad Mansoor Javaid ${ }^{1}$; Muhammad Arslan Saeed ${ }^{1}$; Hasnain Waheed ${ }^{1 *}$; \\ Muhammad Ather Nadeem ${ }^{1}$; Muhammad Faizan Ahmad²; Ahsan Aziz'; Allah \\ Wasaya; ; Masood lqbal Awan; Athar Mahmood ${ }^{4}$; Rashad Mukhtar Balal ${ }^{5}$
}

\section{Highlights}

The Camelina sativa (L.) accessions responds variably to various rates of $\mathrm{P}$ fertilizer.

Australian accession performed better in terms of quality traits than Canadian.

The Canadian was superior in terms of seed yield.

Increases in $\mathrm{P}$ rates impart positive impact on $\mathrm{C}$. sativa accessions.

The $60 \mathrm{~kg} \mathrm{P} \mathrm{ha}^{-1}$ was most effective to achieve optimum yield and profitability.

Abstract

Camelina sativa (L.) Crantz is an emerging oil seed crop and research information on its response to different levels of phosphorous $(P)$ fertilizer is lacking. The two years study was performed to investigate the response of $C$. sativa to various rates of $P$ fertilizer. The experiments were laid out in Randomized Complete Block Design (RCBD) with factorial arrangement having four replications. The $\mathrm{P}$ was applied in soil at the rate of $0,30,40$ and $60 \mathrm{~kg} \mathrm{ha}^{-1}$ to two C. sativa accessions namely Canadian and Australian. Soil applied phosphorus rates had significant effects on the growth, yield and quality of $C$. sativa and two accessions were varied to each other. Australian accession performed better in terms of quality traits and Canadian

1 Department of Agronomy, College of Agriculture, University of Sargodha, Sargodha, Pakistan. E-mail: mmansoorjavaid@gmail.com; saeedarslan04@gmail.com; hasnainwaheed90@yahoo.com; ather.nadeem@uos. edu.pk; drahsanaziz@gmail.com

2 Department of Plant Breeding and Genetics, College of Agriculture, University of Sargodha, Pakistan. E-mail: faizanahmad484@yahoo.com

${ }^{3}$ Department of Agronomy, College of Agriculture, BZU Bahadur Sub-Campus, Layyah, Pakistan. E-mail: wasayauaf@ gmail.com

${ }^{4}$ Department of Agronomy, University of Agriculture, Faisalabad, Pakistan. E-mail: masood.awan@uaf.edu.pk; athar. mahmood@uaf.edu.pk

5 Department of Horticulture, College of Agriculture, University of Sargodha, Pakistan. E-mail: uaf_rashad@yahoo.com

* Author for correspondence

Received: Nov. 28, 2020 - Approved: May 05, 2021 
was superior in terms of seed yield. An increase in $\mathrm{P}$ rate improved growth, yield and quality and $60 \mathrm{~kg} \mathrm{P} \mathrm{ha-1}^{-1}$ resulted in maximal crop growth rate (6.79), seed yield (1239 $\left.\mathrm{kg} \mathrm{ha}^{-1}\right)$, total $P$ uptake $(0.67 \%)$ and oil contents (39.8\%). The regression model estimated that each increment in $\mathrm{P}$ rate increased the seed yield by 11.5 and $11.2 \mathrm{~kg} \mathrm{ha}^{-1}$ in Canadian and Australian accessions, respectively. Conclusively, increases in $\mathrm{P}$ rates $(0$ to 60 $\mathrm{kg} \mathrm{ha}^{-1}$ ) impart a positive impact on $C$. sativa accessions and $60 \mathrm{~kg} \mathrm{P} \mathrm{ha}^{-1}$ was most effective to achieve optimum yield and profitability.

Key words: Fertilization. Oil contents. Seed P uptake. Crop growth rate.

\section{Resumo}

Camelina sativa (L.) Crantz é uma cultura de sementes oleaginosas emergente e faltam informações de pesquisa sobre sua resposta a diferentes níveis de fertilizante de fósforo $(P)$. O estudo de dois anos foi realizado para investigar a resposta de $C$. sativa a várias doses de fertilizante $P$. Os experimentos foram dispostos em blocos casualizados em arranjo fatorial com quatro repetições. O P foi aplicado em solo na proporção de 0, 30, 40 e $60 \mathrm{~kg} \mathrm{ha}^{-1}$ em dois acessos de C. sativa, canadenses e australianos. As doses de $P$ aplicadas no solo tiveram efeitos significativos sobre o crescimento, rendimento e qualidade de $C$. sativa e dois acessos foram variados entre si. O acesso australiano teve melhor desempenho em termos de características de qualidade e o canadense foi superior em termos de rendimento de sementes. $O$ aumento na taxa de $\mathrm{P}$ melhorou o crescimento, rendimento e qualidade e $60 \mathrm{~kg} \mathrm{P}$ ha-1 resultou em taxa máxima de crescimento da cultura $(6,79)$, rendimento de sementes $\left(1239 \mathrm{~kg} \mathrm{ha}^{-1}\right)$, absorção total de $P(0,67 \%)$ e teor de óleo (39,8 \%). O modelo de regressão estimou que cada incremento na dose de P aumentou a produtividade de sementes em 11,5 e 11,2 kg ha-1 nos acessos canadense e australiano, respectivamente. Conclusivamente, aumentos nas doses de $\mathrm{P}\left(0\right.$ a $\left.60 \mathrm{~kg} \mathrm{ha}^{-1}\right)$ conferem um impacto positivo sobre os acessos de C. sativa e $60 \mathrm{~kg} \mathrm{P}$ ha-1 foram mais eficazes para atingir rendimento e lucratividade ideais.

Palavras-chave: Fertilização. Teor de óleo. Absorção de P na semente. Taxa de crescimento da cultura.

\section{Introduction}

Camelina sativa (L.) Crantz is an oil seed species also recognized as camelina, gold of pleasure or false flax (Zohary, Hopf, \& Weiss, 2012; Solis, Vidal, Paulino, Johnson, \& Berti, 2013). The main product from C. sativa is its seed oil, which is rich in fatty acids with $38 \%$ alpha-linolenic acid and $15 \%$ linoleic acid (Zubr, 2003). Worldwide, its seeds are being used for low-caste biodiesel production (Solis et al., 2013). Worldwide, camelina is being cultivated on 2-3 million hectares with an average yield of $2.5 \mathrm{t} \mathrm{ha}^{-1}$ (Dobre et al., 2014). In Pakistan, camelina is not being cultivated on large areas but has great potential as feedstock for biodiesel production.

Phosphorus $(\mathrm{P})$ is the second most importantessentialmacronutrient, vitalfor crop growth and soils are usually supplemented with $P$ in the form of chemical fertilizers (Ahmada, Uddina, Ahmada, \& Islam, 2013). Phosphorus is not just significant for getting enhanced growth and development of field crops but also essential for the improvement of quality of distinct parameters, while its reduction may cause a decrease in crop growth, late flowering and maturity and ultimately yield of crops can be reduced up to 10-15\% (Shenoy \& Kalagudi, 2005; Waraich, Ahmad, Ahmad, Saifullah, \& 
Ashraf, 2015). Thus, efficient $P$ management is necessary to enhance crop productivity (Aziz et al., 2006). Different approaches are adopted for the effective utilization of applied P by plants (Alam, Shah, \& Akhtar, 2003; Aziz et al., 2006; Fageria, Baligar, Moreira, \& Moraes, 2013) e.g. the specific behavior of a plant to efficaciously acquire and utilize the nutrient in the deficient environment (Gill, Mansoor, Aziz, Rahmatullah, \& Akhtar, 2002). There are several physiological and morphological mechanisms in soil involved to cope with the $P$ deficiency. Crop species and even cultivars within the species fluctuate genetically in these mechanisms and hence showed variable responses to $\mathrm{P}$ deficiency stress (Aziz, Rahmatullah, Maqsood, \& Mansoor, 2005).

Camilena sativa as a short season crop with a low fertility requirement may have the potential for biodiesel production (Gugel \& Falk, 2006). Studies showed that it can be grown on marginal land where other crops cannot grow. Seed yield of $C$. sativa was increased with use of a sufficient amount of $\mathrm{P}$ (Bugnarug \& Borcean, 2000). One of the constraints in oil seeds production is imbalanced and insufficient nutrients supply (Aziz et al., 2006) particularly reduced availability of $\mathrm{P}$ is critical. It is important to study the response of oil seed crops to $P$ fertilizer since this element may impact on the oil contents of the species. According to Malavolta (1989), $P$ fertilization in a suitable amount encourages root development, make sure a vigorous establishment, fast physiological maturity, start flowering, helps seed formation, increases to tolerate cold and increases grain yield (Ali, Hussain, Tanveer, Nadeem, \& Haq, 2002; Rogério, Silva, Santos, \& Poletine, 2013). Numerous studies about the effect of $\mathrm{N}$ application on growth and yield of $C$. sativa have been reported (Urbaniak, Caldwell,
Zheljazkov, Lada, \& Luan, 2008; Končius \& Karčauskiene, 2010) but $P$ requirement is need to be investigated.

Therefore, $\mathrm{P}$ use has become a necessary practice for oil-producing plants. It is also necessary to check the response of newly introduced crop in a specific region to a specific nutrient. However, the decisive reports for the $P$ management of $C$. sativa in Pakistan have not been directed before. The objective of the present study was to find out which $P$ rate is best for maximizing the $C$. sativa seed yield, oil contents and $\mathrm{P}$ uptake.

\section{Materials and Methods}

\section{Site description, soil status and design}

The experiments were conducted at the Agronomic Research area, College of Agriculture, University of Sargodha, Sargodha (32.0 $0^{\circ} \mathrm{LN}$ and $72.6^{\circ} \mathrm{LE}$ ) Pakistan during spring season 2014 and 2015. Soil test samples were collected at planting time from a depth of 0-10, 10-15, and $15-20 \mathrm{~cm}$. The five subsamples were taken in each replicate then bulked to one sample in each replicate and depth. Soil analysis was conducted, and organic matter (OM) was determinate by acid digestion and colorimetry, and $\mathrm{pH}$ in water, the transnitration of salicylic acid method was used to determine the baseline $\mathrm{N}$ fertility level of each sample (Vendrell \& Zupancic, 1990; Franzen \& Cihacek, 1996). P-Olsen method was used for $P$ determination (Olsen, Cole, Watanabe, \& Dean, 1954), K extractable was determined with ammonium acetate solution $1 \mathrm{ML}^{-1}$ to $\mathrm{pH} 7$ (Haby, Russelle, \& Skogley, 1990). Soil analysis of the experimental site was indicated in table 1. Soil $\mathrm{pH}$ and organic matter ranged between $7.1-$ to $7.7 \%$ and $1.4-$ to $1.4 \%$, respectively, at 
0-20 cm depth. However, the N, P, and K level was low to medium at the experimental site. The experiments were laid out in a randomized complete block design with a factorial arrangement having four replicates. The treatments were comprised of four rates of $P$ $\left(0,30,40\right.$, and $\left.60 \mathrm{~kg} \mathrm{ha}^{-1}\right)$ and two accessions of C. sativa (Canadian and Australian accession) were imported from Canada and Australia. The $P$ rates were selected based on the range of $P$ requirement of brassica family crops as no recommendation of $\mathrm{P}$ is reported for $\mathrm{C}$. sativa.

\section{Table 1}

\section{Soil analysis of experimental site (Presented data is the average of two years)}

\begin{tabular}{|ccccc|}
\hline & \multicolumn{4}{c|}{ Soil sample depth $(\mathrm{cm})$} \\
\cline { 2 - 5 } Characteristic & $0-10$ & $10-15$ & $15-20$ & Mean \\
\hline Soil pH & 7.10 & 7.23 & 7.70 & 7.34 \\
\hline Organic Matter (\%) & 1.39 & 1.20 & 1.06 & 1.20 \\
\hline Total Nitrogen (\%) & 0.063 & 0.064 & 0.053 & 0.060 \\
\hline Available P $\left(\mathrm{mg} \mathrm{kg}^{-1}\right)$ & 5.1 & 7.4 & 10.25 & 7.58 \\
\hline Available K $\left(\mathrm{mg} \mathrm{kg}^{-1}\right)$ & 188 & 168 & 126 & 161 \\
\hline
\end{tabular}

\section{Experimental management}

Before seedbed preparation, presoaking irrigation was applied. When soil reached to proper moisture level, seedbed was prepared by cultivating the soil 2 times with tractor mounted cultivator each followed by planking. The net plot size was $1.8 \mathrm{~m} \times 3 \mathrm{~m}$ having row to row spacing $20 \mathrm{~cm}$ and plant to plant distance $20 \mathrm{~cm}$. Camelina crop was sown during the $1^{\text {st }}$ week of March 2014 and 2015 with the help of a single row hand drawn drill, using seed rate of $2 \mathrm{~kg} \mathrm{acre}^{-1}$ and an interplant distance of 12 inches was maintained by thinning at 4-6 leaf stage of the crop. Nitrogen $(\mathrm{N})$ and potassium (K) fertilizer was applied at the rate of 75 and $50 \mathrm{~kg} \mathrm{ha}^{-1}$ respectively in all plots. For application of $\mathrm{P}$ fertilizer diammonium Phosphate (DAP) was used. Half dose of $\mathrm{N}$ and required dose of $\mathrm{P}$ and $\mathrm{K}$ was applied at sowing in each plot, while remaining
$\mathrm{N}$ was applied with first irrigation. All other agronomic practices were kept normal and uniform for all the treatments. Plant protection measures were adopted to keep the crop free from weeds, insect pests and diseases. Insecticide Larsban $^{\circledR}$ (chloropyriphas) @ 1 L ha-1 was sprayed once for the control of red pumpkin beetle in both years.

\section{Growth and seed yield and its components}

Plant height was taken by randomly selecting the five plants from each plot and height of each plant was measured from soil surface to the tip of plant with the help of a meter rod and then average height per plant was calculated. Days to flower initiations were observed by selecting five plants at random from each plot and days to flower initiation were calculated from sowing to flowering. 
Crop growth rate was determined at fortnight intervals by taking five plants at random from each plot. The sampling was initiated 30 days after sowing and terminated at the harvest of crop. After harvesting, each sample was weighed to determine fresh weight. Each plant sample was chaffed, thoroughly mixed and then sun dried. Afterward samples were placed in an oven at $70^{\circ} \mathrm{C}+5^{\circ} \mathrm{C}$ to dry the plant material to their constant dry weight. Then dry weight per plant was calculated by using the following equation.

$$
C G R=\frac{\mathrm{W} 2-\mathrm{W} 1}{\mathrm{~T} 2-\mathrm{T} 1}
$$

Where

$\mathrm{W}_{2}=$ Dry weight $\mathrm{m}^{-2}$ at second harvest

$\mathrm{W}_{1}=$ Dry weight $\mathrm{m}^{-2}$ at first harvest

$\mathrm{T}_{2}=$ Time corresponding to second harvest

$\mathrm{T}_{1}=$ Time corresponding to first harvest

Mean CGR was calculated by averaging all CGRs calculated at each destructive harvest.

Yield components, number of pods per plant, number of seeds per pod, 1000-grains weight were recorded according to standard procedure. For biological yield, the crop was harvested at physiological maturity and left in the respective sub plots for few days for sun drying. The sun-dried bundles were weighed with the help of a spring balance to determine the total biomass of each plot and then converted into $\mathrm{kg} \mathrm{ha}^{-1}$. The bundles of each plot were threshed manually, and the seed obtained was weighed and then converted into seed yield $\left(\mathrm{kg} \mathrm{ha}^{-1}\right)$. Harvest index is described as a ratio of grain yield to biological yield. It was determined by using the following formula.

\section{Seed oil content (\%)}

The oil contents in C. sativa seeds were determined through the petroleumether Soxhlet extraction apparatus. The $C$. sativa seeds were dried in an oven at $50^{\circ} \mathrm{C}$ for 24 hours. Seed samples, each of $5.0 \mathrm{~g}$, were crushed gently using a pestle and mortar and placed in a thimble. The seed samples were cycled in the Soxhlet apparatus for 3 hours. The remaining seeds in the thimble were dried at $50^{\circ} \mathrm{C}$ for 24 hours and weighed. Oil contents (\%) were calculated according to the following equation:

$$
\text { Oil content }(\%)=\left(W_{1}-W_{2}\right) / W_{1} \times 100
$$

Where,

$W_{1}$ is the weight of dried sample before loading in the thimble, $W_{2}$ is the weight of the dried sample after oil extraction.

\section{Seed phosphorus uptake (\%)}

Seed samples were dried at $70^{\circ} \mathrm{C}$ in an oven till constant dry weight. Dried seed samples were then ground in a Wiley Mill to pass through one $\mathrm{mm}$ sieve. Uniform samples $(0.5 \mathrm{~g})$ were then digested in di-acid mixture of nitric and perchloric acid (3:1). Phosphorus concentration was determined from digested samples using vanadate-molybdate colorimetric method (Kitson \& Mellon, 1944).

Data of crop growth rate, seed yield, seed oil contents against $P$ rates and seed oil contents (\%) against seed $P$ uptake (\%) was interpreted by fitted regression analysis.

$$
\mathrm{HI}(\%)=\frac{\text { Grain Yield }}{\text { Biological yield }} \times 100
$$




\section{Statistical analysis}

Data of both years was non- significant, and the data was pooled over the year. The collected data were analyzed statistically by using Statistix 8.1 analysis of variance (ANOVA) technique and significant of treatment means were compared using Tukey's (HSD) test at 5\% probability level (Steel, Torrie, \& Dicky, 1997). The regression analysis was performed by using Sigma Plot 2008 (Version 11.0). Average of both year's data was presented for each parameter.

\section{Results and Discussion}

\section{Growth and yield traits}

Effect of $P$ rates on plant height of both accessions of $C$. sativa was significant (Table 2 ). Canadian accession produced taller plant than Australian accession. $\mathrm{P}$ application resulted in an increase in plant height with increase in rate. Among the $P$ rate maximum plant height of $C$. sativa is recorded with $60 \mathrm{~kg} \mathrm{P} \mathrm{ha}^{-1}$ followed by that of $40 \mathrm{~kg} \mathrm{P} \mathrm{ha}^{-1}$. The interactive effect of $P$ and $C$. sativa accessions showed that Canadian accession performed well with a higher rate of $\mathrm{P}$ for maximum plant height $(81.47 \mathrm{~cm})$. Camelina sativa (L.) Crantz is a crop which is likely to grow with minimal inputs in various soil types (Malhi et al., 2014). The availability of $P$ in soil encourages the growth of root that might be helpful for P uptake (Borges \& Mallarino, 2001). In our study results indicated that the plant height of both accessions improved significantly with higher rate of $\mathrm{P}\left(60 \mathrm{~kg} \mathrm{P} \mathrm{ha}^{-1}\right)$ might be due to balanced availability of $P$ which enhanced the availability of some micro-nutrients. Solis et al. (2013) reported that plant height was increased significantly with the increasing $P$ rates. These results are also in agreement with those of Idris, Mahmood and Malik (1989) who reported similar findings for $\mathrm{P}$ uptake.

The flowering was initiated two days earlier in Australian accession than Canadian accession (Table 2). Maximum days to flower initiate (42.3) were taken by C. sativa when no $P$ was applied. Whereas minimum days to initiate flowers were taken where $60 \mathrm{~kg} P$ ha-1 was applied. Interaction of $P$ rates $\times$ accessions showed that $60 \mathrm{~kg} \mathrm{P}^{-1}$ caused minimum days (38.2) to initiate flower in Australian accession.

\section{Table 2}

Plant height $(\mathrm{cm})$, days to flower initiations and crop growth rate $\left(\mathrm{g} \mathrm{m}^{-2}\right.$ day $\left.^{-1}\right)$ as influenced by different phosphorous rates in two accessions of C. sativa (Presented data is the average of two years)

\begin{tabular}{|c|c|c|c|c|c|c|c|c|c|}
\hline \multirow{3}{*}{$\begin{array}{l}\text { Phosphorous } \\
\qquad\left(\mathrm{kg} \mathrm{ha}^{-1}\right)\end{array}$} & \multicolumn{3}{|c|}{ Plant height (cm) } & \multicolumn{3}{|c|}{ Days to flower initiations } & \multicolumn{3}{|c|}{ Crop growth rate $\left(\mathrm{g} \mathrm{m}^{-2}\right.$ day $\left.^{-1}\right)$} \\
\hline & \multicolumn{2}{|c|}{ Accessions } & \multirow{2}{*}{ Mean } & \multicolumn{2}{|c|}{ Accessions } & \multirow{2}{*}{ Mean } & \multicolumn{2}{|c|}{ Accessions } & \multirow{2}{*}{ Mean } \\
\hline & Canadian & Australian & & Canadian & Australian & & Canadian & Australian & \\
\hline 0 (Control) & $70.3 \mathrm{~d}$ & $65.14 \mathrm{~g}$ & 67.7 D & 43.1 a & $41.5 \mathrm{c}$ & $42.3 \mathrm{~A}$ & $5.44 \mathrm{~d}$ & $5.66 \mathrm{~d}$ & $5.55 \mathrm{C}$ \\
\hline 30 & $75.4 \mathrm{c}$ & $66.9 \mathrm{f}$ & $71.2 \mathrm{C}$ & $42.0 \mathrm{~b}$ & $40.4 \mathrm{~d}$ & $41.2 \mathrm{~B}$ & $5.66 \mathrm{~d}$ & $6.10 \mathrm{c}$ & $6.02 \mathrm{~B}$ \\
\hline 40 & $79.1 \mathrm{~b}$ & $69.2 \mathrm{e}$ & $74.2 \mathrm{~B}$ & $40.4 \mathrm{~d}$ & $39.06 \mathrm{e}$ & $39.7 \mathrm{C}$ & $6.09 c$ & $6.68 b$ & $6.38 \mathrm{AB}$ \\
\hline 60 & $81.4 \mathrm{a}$ & $70.2 \mathrm{~d}$ & $75.8 \mathrm{~A}$ & $39.2 \mathrm{e}$ & $38.2 \mathrm{f}$ & $38.7 \mathrm{D}$ & $6.57 b$ & $7.01 \mathrm{a}$ & $6.79 \mathrm{~A}$ \\
\hline $\begin{array}{c}\text { Means of } \\
\text { accessions }\end{array}$ & $76.6 \mathrm{~A}$ & $67.9 \mathrm{~B}$ & & $41.2 \mathrm{~A}$ & $39.8 \mathrm{~B}$ & & $6.36 \mathrm{~A}$ & $6.01 \mathrm{~B}$ & \\
\hline HSD (0.05) & \multicolumn{2}{|c|}{0.12} & 0.23 & \multicolumn{2}{|c|}{0.127} & 0.24 & \multicolumn{2}{|c|}{0.08} & 0.14 \\
\hline
\end{tabular}

Values in the column or means of accessions within the row sharing the same letter did not differ significantly with each other at $5 \%$ probability level. Values with capital letters are the main effect and with small letters are interactive effects. 
Higher crop growth rate was observed in Canadian accession compared to Australian accession (Table 2). The increasing rate of $P$ also had significant effects on crop growth rate of $C$. sativa. Maximum crop growth rate (6.79 $\mathrm{g} \mathrm{m}^{-2}$ per day) was observed with soil applied $60 \mathrm{~kg} \mathrm{P}^{-1}$, which was followed by that of $40 \mathrm{~kg} \mathrm{P} \mathrm{ha}^{-1}$. Data indicated that interaction of $P$ with accessions was significant and Australian accession was superior in terms of crop growth rate at rate of 40 and $60 \mathrm{~kg} \mathrm{P} \mathrm{ha}^{-1}$, while minimum crop growth rate was obtained in Canadian accession when no P was applied. The regression equation predicted that if the rate of $\mathrm{P}$ increased by $1.0 \mathrm{~kg} \mathrm{ha}^{-1}$ then the crop growth rate increased by $0.2 \mathrm{~g} \mathrm{~m}^{-2}$ day $^{-1}$ in both accessions (Figure 1). Model also estimated that crop growth rate would be 5.61 and $5.41 \mathrm{~g}$ $\mathrm{m}^{-2}$ day $^{-1}$ with no application of $\mathrm{P}$.

The flower initiations was observed 2-3 days earlier with $60 \mathrm{~kg} \mathrm{P} \mathrm{ha}^{-1}$ than control may be due to maximal uptake of $P$ by roots that enhanced the growth of $C$. sativa that brings early flowering. In our study, crop growth rate increased with $60 \mathrm{~kg} \mathrm{P} \mathrm{ha}^{-1}$ could be the result of superior roots leading to better soil moisture extraction, as a likely response to high $P$ uptake. The $P$ is essential for getting enhanced growth and development of field crops, while its reduction may cause a decrease in crop growth, produce late flowering and maturity (Shenoy \& Kalagudi, 2005). It brings early root development and accelerates plant maturity that significantly influences the plant growth and development (Irshad et al., 2015). Our results are further supported by those of Baghestani et al. (2008) who stated that by increasing $P$ rates, growth of the plant increased and day to flowering initiation decrease significantly. Mandal \& Sinha (2003) also recorded that higher fertilizer levels resulted in maximum crop growth rate.

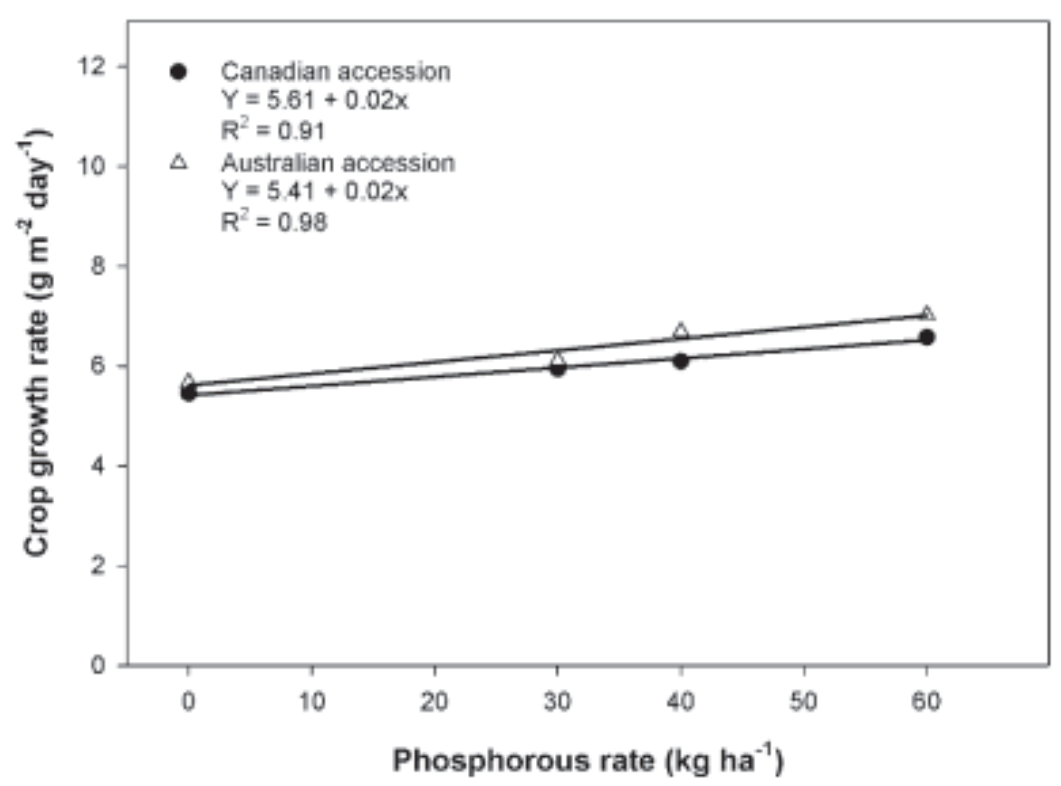

Figure 1. Regression analysis for crop growth rate of two Camelina sativa L. accessions as influenced by different phosphorous rates. 
Number of pods per plant deferred significantly between the accessions. Canadian accession was leading on Australian accession in case of number of pods per plant. Table 3 showed that $P$ rates at 60 or $40 \mathrm{~kg} \mathrm{ha}^{-1}$ resulted in maximum number of pods per plant (344.1 and 342.2). However, highest number of pods per plant occurred with Australian accession with $60 \mathrm{~kg} \mathrm{P}^{\mathrm{P}} \mathrm{a}^{-1}$ fallowed by $40 \mathrm{~kg}$
$\mathrm{P}$ ha $^{-1}$ in same cultivar. Australian accession recorded a greater number of seeds per pod (12.3) than Canadian accession (10.0). The impact of different $P$ rates on number of seeds per pod was non-significant. Interaction of $P$ rates $\times$ accessions was significant and showed that maximum number of seeds per pod (13.0) was recorded in Australian accession with 60 $\mathrm{kg} \mathrm{P} \mathrm{ha}^{-1}$ (Table 3).

\section{Table 3}

Number of pods per plant, number of seed per pod and 1000-grain weight (g) as influenced by different phosphorous rates in two accessions of C. sativa (Presented data is the average of two years)

\begin{tabular}{|c|c|c|c|c|c|c|c|c|c|}
\hline \multirow{3}{*}{$\begin{array}{l}\text { Phosphorous } \\
\qquad\left(\mathrm{kg} \mathrm{ha}^{-1}\right)\end{array}$} & \multicolumn{3}{|c|}{ Number of pods per plant } & \multicolumn{3}{|c|}{ Number of seed per pod } & \multicolumn{3}{|c|}{ 1000-grain weight (g) } \\
\hline & \multicolumn{2}{|c|}{ Accessions } & \multirow{2}{*}{ Mean } & \multicolumn{2}{|c|}{ Accessions } & \multirow{2}{*}{ Mean } & \multicolumn{2}{|c|}{ Accessions } & \multirow{2}{*}{ Mean } \\
\hline & Canadian & Australian & & Canadian & Australian & & Canadian & Australian & \\
\hline 0 (Control) & 327.1 ef & $325.2 f$ & $337.1 \mathrm{~B}$ & $10.0 \mathrm{~cd}$ & $12.0 \mathrm{ab}$ & $11.0 \mathrm{~A}$ & $1.09 \mathrm{~d}$ & $1.31 \mathrm{~cd}$ & $1.20 \mathrm{C}$ \\
\hline 30 & 329.9 e & $347.0 \mathrm{c}$ & $327.5 \mathrm{C}$ & $10.2 \mathrm{bcd}$ & $12.2 \mathrm{a}$ & $11.2 \mathrm{~A}$ & $1.20 \mathrm{~cd}$ & $1.38 \mathrm{bc}$ & $1.29 \mathrm{C}$ \\
\hline 40 & $332.1 \mathrm{de}$ & $352.3 b$ & $342.2 \mathrm{~A}$ & $10.0 \mathrm{~cd}$ & $11.7 \mathrm{abc}$ & $10.8 \mathrm{~A}$ & $1.40 \mathrm{bc}$ & $1.70 \mathrm{a}$ & $1.62 \mathrm{~B}$ \\
\hline 60 & $335.1 \mathrm{~d}$ & $353.2 \mathrm{a}$ & $344.1 \mathrm{~A}$ & $9.7 \mathrm{~d}$ & $13.0 \mathrm{a}$ & $11.6 \mathrm{~A}$ & $1.62 a b$ & $1.84 \mathrm{a}$ & $1.73 \mathrm{~A}$ \\
\hline $\begin{array}{c}\text { Means of } \\
\text { accessions }\end{array}$ & $331.1 \mathrm{~A}$ & $244.4 \mathrm{~B}$ & & $10.0 \mathrm{~B}$ & $12.3 \mathrm{~A}$ & & $1.33 \mathrm{~B}$ & $1.56 \mathrm{~A}$ & \\
\hline HSD (0.05) & & .99 & 24.61 & & & 1.08 & & 08 & 0.16 \\
\hline
\end{tabular}

Values in the column or means of accessions within the row sharing the same letter did not differ significantly with each other at $5 \%$ probability level. Values with capital letters are the main effect and with small letters are interactive effects.

Different $P$ rates significantly improved the 1000-grain weight in both accessions; however, an increase in 1000-grain weight due to $P$ rates was more in Australian accession than in Canadian accession (Table 3). Phosphorus at $60 \mathrm{~kg} \mathrm{P} \mathrm{ha-1}$ recorded maximum 1000-grain weight among all the treatments. Whereas minimum 1000-grain weight was recorded in plots where no $\mathrm{P}$ or 30 $\mathrm{kg} \mathrm{P} \mathrm{ha-1}$ was applied. The interactive effect showed that Australian accession proved to be superior in terms of 1000-grain weight of C. sativa at $P$ rate of 40 or $60 \mathrm{~kg} \mathrm{P} \mathrm{ha}^{-1}$. All $P$ treatments construct a significant effect on seed yield of both accessions as compared to control (Table 4).

The seed yield of Canadian accession was significantly higher than Australian accession. The application of $60 \mathrm{~kg} P$ ha-1 produced the optimum seed yield which was followed by $40 \mathrm{~kg} \mathrm{P} \mathrm{ha}^{-1}, 30 \mathrm{~kg} \mathrm{P} \mathrm{ha}^{-1}$ and $0 \mathrm{~kg}$ $\mathrm{P} \mathrm{ha}^{-1}$. Compared with control, the seed yield of $C$. sativa with 60,40 , and $30 \mathrm{~kg} \mathrm{P} \mathrm{ha}^{-1}$ were enhanced significantly by $724.1,270.7$, and $245.1 \mathrm{~kg} \mathrm{ha}^{-1}$, respectively (Table 4). Interaction of $P$ rates $\times$ accessions showed that highest 
seed yield $\left(1,249.7 \mathrm{~kg} \mathrm{ha}^{-1}\right)$ was observed where $60 \mathrm{~kg} \mathrm{P} \mathrm{ha}^{-1}$ was applied in Canadian accession. Minimum seed yield (480.2 $\mathrm{kg} \mathrm{ha}^{-1}$ ) was measured in Australian accession where no $P$ was applied. From the regression model it was estimated that with no $P$ application, seeds yield of Canadian accession was 462.4 and $447.7 \mathrm{~kg} \mathrm{ha}^{-1}$ in Canadian accession and Australian accession, respectively, however, each increment in $\mathrm{P}$ rate increased the seed yield by $11.5 \mathrm{~kg} \mathrm{ha}^{-1}$ in Canadian accession and $11.2 \mathrm{~kg} \mathrm{ha}^{-1}$ in Australian accessions (Figure 2).

The C. sativa yield and its components such as seed yield, number of pods per plant and 1000-grain weight were recorded highest with higher rate of $P$ that might had increased the availability and absorption of nutrients, which enhanced the leaf area, formation of chlorophyll and photosynthesis. However, higher number of branches and leaf area is directly proportional to photosynthates production (H. B. Ahmad et al., 2014). This might be the reasons for increased pods per plant, 1000-grain weight and seed yield. Increased 1000-grain weight and seed yield may be due to better translocation of photosynthates to sink (seed). Phosphorus significantly influences plant growth, early root formation, pod and seed formation, seed weight and seed yield (Irshad et al., 2015).
Seed yield of $C$. sativa was increased with use of sufficient amount of P (Bugnarug \& Borcean, 2000). Similar results are also reported by Malhi et al. (2014) who described that higher seed yields of canola, flax and mustard were obtained with adequate supply of nutrients (NPK). In soybean, number of pods per plant and seed yield increased significantly with 80 $\mathrm{kg} \mathrm{P} \mathrm{ha}^{-1}$ (Ramasamy, Srinivasan, \& Sankaran, 2000). According to Sanusan, Polthanee, Seripong, Audebert and Mouret (2009) time and rate of $P$ application is the key factors that determine the improvement in crop yield. They also revealed that grain yield of rice was highest with $60 \mathrm{~kg} \mathrm{P} \mathrm{ha}^{-1}$.

The Table 4 indicated that biological yield was significantly affected by different accessions of $C$. sativa and $P$ rates. The biological yield of Australian accession was higher $\left(2,521.4 \mathrm{~kg} \mathrm{ha}^{-1}\right)$ as compared with Canadian accession $\left(2,500.7 \mathrm{~kg} \mathrm{ha}^{-1}\right)$. Increasing $P$ fertilizer rate resulted in an increased biological yield. Among the $P$ rates, maximum biological yield of $C$. sativa was recorded with $60 \mathrm{~kg} \mathrm{P}^{\mathrm{P}} \mathrm{a}^{-1}$ followed by that of $40 \mathrm{~kg} \mathrm{P} \mathrm{ha-1}$. The interactive effect of $P$ and accessions showed that $60 \mathrm{~kg} \mathrm{P} \mathrm{ha}^{-1}$ was more effective than other $P$ rates in increasing the biological yield of Australian accession. 


\section{Table 4}

Seed yield $\left(\mathrm{kg} \mathrm{ha}^{-1}\right)$, biological yield ( $\left.\mathrm{kg} \mathrm{ha}^{-1}\right)$ and harvest index (\%) as influenced by different phosphorous rates in two accessions of $C$. sativa (Presented data is the average of two years)

\begin{tabular}{|c|c|c|c|c|c|c|c|c|c|}
\hline \multirow{3}{*}{$\begin{array}{l}\text { Phosphorous } \\
\left(\mathrm{kg} \mathrm{ha}^{-1}\right)\end{array}$} & \multicolumn{3}{|c|}{ Seed yield $\left(\mathrm{kg} \mathrm{ha}^{-1}\right)$} & \multicolumn{3}{|c|}{ Biological yield $\left(\mathrm{kg} \mathrm{ha}^{-1}\right)$} & \multicolumn{3}{|c|}{ Harvest index (\%) } \\
\hline & \multicolumn{2}{|c|}{ Accessions } & \multirow{2}{*}{ Mean } & \multicolumn{2}{|c|}{ Accessions } & \multirow{2}{*}{ Mean } & \multicolumn{2}{|c|}{ Accessions } & \multirow{2}{*}{ Mean } \\
\hline & Canadian & Australian & & Canadian & Australian & & Canadian & Australian & \\
\hline 0 (Control) & $549.6 \mathrm{~g}$ & $480.2 \mathrm{~h}$ & $514.9 \mathrm{D}$ & $2360.5 \mathrm{~h}$ & $2400.3 \mathrm{~g}$ & $2380.4 \mathrm{D}$ & $23.3 \mathrm{f}$ & $20.1 \mathrm{~g}$ & $21.7 \mathrm{D}$ \\
\hline 30 & $650.1 \mathrm{f}$ & $870.0 d$ & $760.0 \mathrm{C}$ & 2480.8 e & $2450.1 \mathrm{f}$ & $2465.0 \mathrm{C}$ & $26.3 d$ & $25.2 \mathrm{e}$ & $25.7 \mathrm{C}$ \\
\hline 40 & $899.9 \mathrm{c}$ & $671.3 \mathrm{e}$ & $785.6 \mathrm{~B}$ & $2550.5 d$ & $2560.8 \mathrm{c}$ & $2555.7 \mathrm{~B}$ & $35.4 \mathrm{c}$ & $26.2 d$ & $30.8 \mathrm{~B}$ \\
\hline 60 & 1249.7 a & $1229.3 b$ & $1239 \mathrm{~A}$ & $2610.9 b$ & $2674.4 \mathrm{a}$ & $2642.6 \mathrm{~A}$ & $47.5 \mathrm{a}$ & $46.1 \mathrm{~b}$ & $46.8 \mathrm{~A}$ \\
\hline $\begin{array}{c}\text { Means of } \\
\text { accessions }\end{array}$ & $837.3 \mathrm{~A}$ & $812.7 \mathrm{~B}$ & & $2500.7 \mathrm{~B}$ & $2521.4 \mathrm{~A}$ & & $33.1 \mathrm{~A}$ & $29.4 \mathrm{~B}$ & \\
\hline HSD (0.05) & \multicolumn{2}{|c|}{0.77} & 1.47 & \multicolumn{2}{|c|}{0.83} & 1.57 & \multicolumn{2}{|c|}{0.12} & 0.23 \\
\hline
\end{tabular}

Values in the column or means of accessions within the row sharing the same letter did not differ significantly with each other at 5\% probability level. Values with capital letters are the main effect and with small letters are interactive effects.

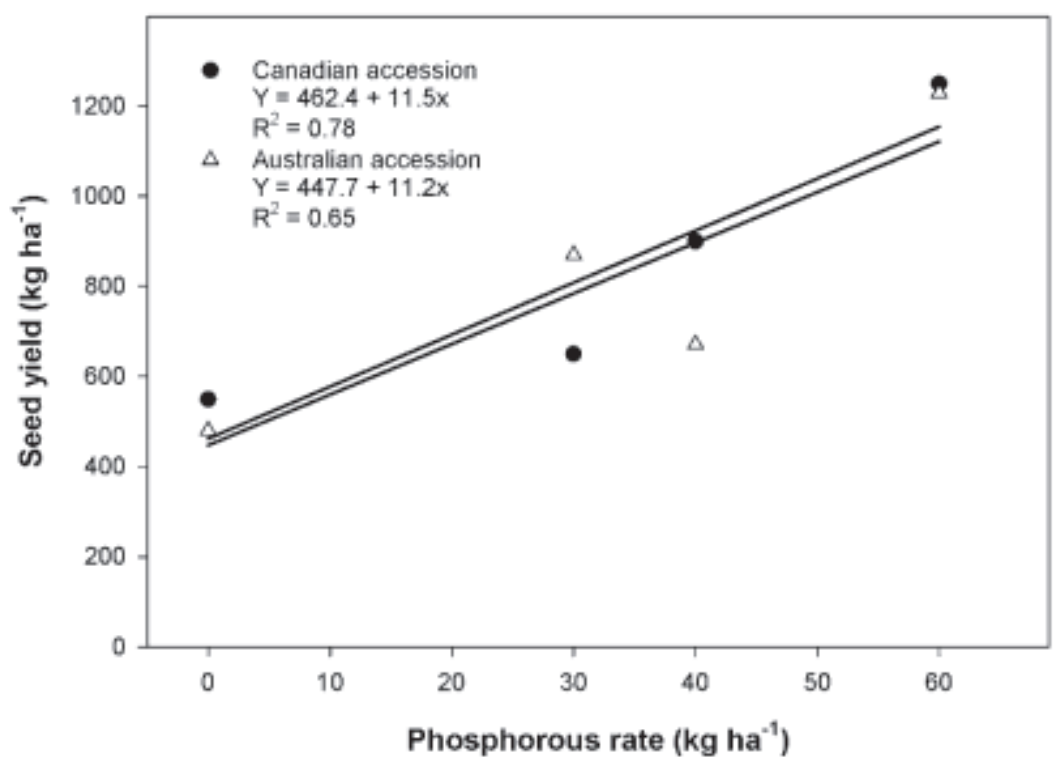

Figure 2. Regression analysis for seed yield of two Camelina sativa L. accessions as influenced by different phosphorous rates.

Among the tested accessions, Canadian accession performed better and gave the maximum harvest index (33.1\%) and Australian accession had lowest harvest index (29.4\%). Among the P application rates maximum harvest index (46.8\%) of $C$. sativa was obtained with $60 \mathrm{~kg} \mathrm{P} \mathrm{ha}^{-1}$, while minimum harvest index (21.7\%) was obtained where no $P$ was applied (Table 4). The interactive effect of $P$ rates $\times$ accessions of $C$. sativa exhibited that maximum harvest index $(47.5 \%)$ was found in Canadian accession where $60 \mathrm{~kg} \mathrm{P}$ ha $^{-1}$ was applied (Table 4). 
Our results showed that biological yield and harvest index of $C$. sativa accessions increased by increasing level of $P$ from 0 to 60 $\mathrm{kg} \mathrm{P} \mathrm{ha}^{-1}$. It might be due to an increase in crop growth rate that produced higher biomass. The results are confirmed with finding of Nutall, Monlin and Smith (1992). The higher rates of $\mathrm{P}$ gave significantly greater biological yield than lower rates of $P$ (Cheema et al., 2001). The results agreed with those of Cheema et al. (2001) who also reported similar findings for harvest index of canola crop. In other oilseeds, harvest index commonly fluctuates between 20 and $35 \%$ like what was observed for $C$. sativa in this study. For instance, harvest index for canola is approximately $30 \%$, for flax $15-$ 25\% (Dash, 2005).

\section{Qualitative traits}

Table 5 indicated that there was no significant difference in seed oil contents of two C. sativa accessions. However, interaction of $\mathrm{P}$ and accessions was significant for seed oil content. Seed oil content increased with increasing $P$ fertilizer rates $(0,30,40$, and $60 \mathrm{~kg}$ $\left.\mathrm{ha}^{-1}\right)$, reaching the maximum (39.8\%) with $60 \mathrm{~kg}$ $P$ ha $^{-1}$ (Table 5). Interaction of $P$ and accessions showed that highest seed oil contents were observed in Australian accession with $60 \mathrm{~kg} \mathrm{P}$ $\mathrm{ha}^{-1}$. Regression equation estimated that each increment in $\mathrm{P}$ rate $\left(\mathrm{kg} \mathrm{ha}^{-1}\right)$ would increase the seed oil contents by $0.11 \%$ in Canadian accession and $0.14 \%$ in Australian accession
(Figure 3). Compared to Canadian, seed of Australian accession recorded more $\mathrm{P}$ uptake but their difference was non-significant (Table 5). However, different $P$ rates, significantly improved the seed $P$ uptake as compared to control. Interaction of $\mathrm{P} \times$ accessions exhibited that maximum seed $P$ uptake was recorded with $60 \mathrm{~kg} \mathrm{P}$ ha $^{-1}$ in Australian accession followed by that of $40 \mathrm{~kg} \mathrm{P} \mathrm{ha-1} \mathrm{in} \mathrm{same}$ accession. Regression model was fitted to the data of seed oil contents and seed $P$ uptake (Figure 4). Model showed linear relationship between these two parameters.

In this study seed oil contents enhanced with increasing rates of P. Malik, Saleem, Sana and Rehman (2004) also reported a similar finding for seed oil contents in sunflower. Our results for oil contents of C. sativa are completely in line with those reported by Sawan, Hafezb, Basyony and Abou-El-Ela (2007) who revealed that high levels of $P$ increased the oil contents of canola. Oil concentration increases with increasing P level (Lickfett, Matthaus, Velasco, \& Mollers, 1999). In our study, seed $P$ uptake (\%) increased with increasing $P$ rates might be due to more availability of $P$. These results are in confirmation with Mohanty, Paikaray and Rajan (2006) who found that P concentration in seeds increased significantly with the application of $P$ fertilizer. The different rates of $P$ influenced the oil contents of linseed and highest oil contents were observed with $90 \mathrm{~kg}$ $P$ ha-1 (Ali et al., 2002). 


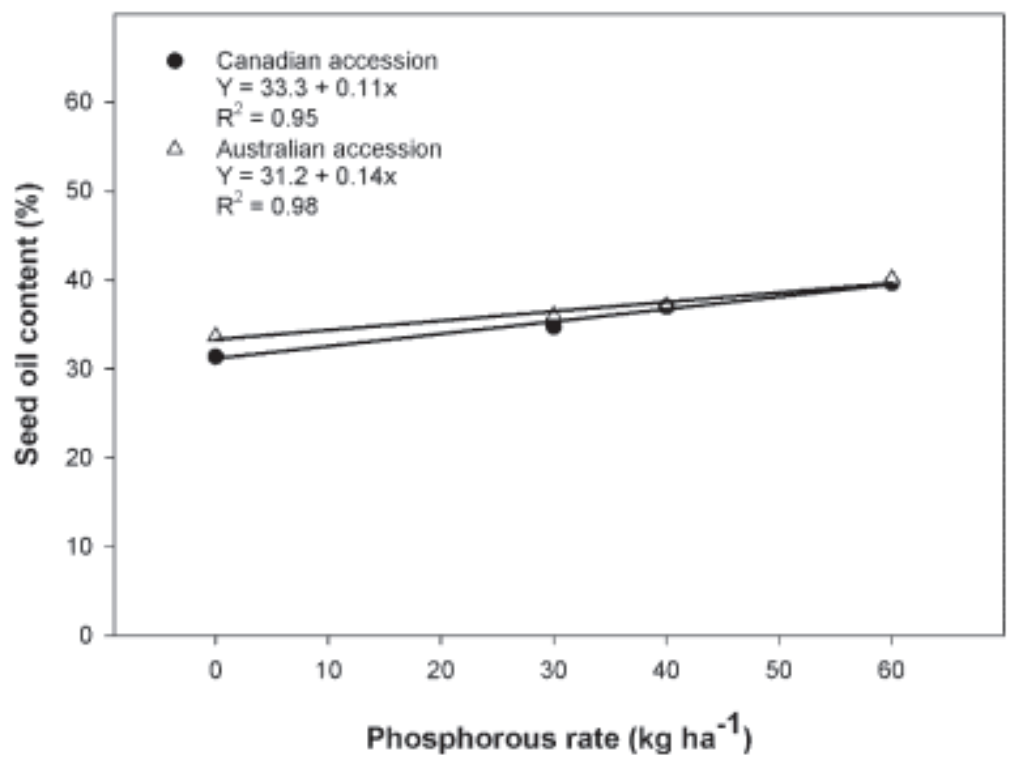

Figure 3. Regression analysis for seed oil content of two Camelina sativa L. accessions as influenced by different phosphorous rates.

\section{Table 5}

Seed oil content (\%) and seed $\mathrm{P}$ uptake (\%) as influenced by different phosphorous rates in two accessions of $C$. sativa (Presented data is the average of two years)

\begin{tabular}{|c|c|c|c|c|c|c|}
\hline \multirow{3}{*}{$\begin{array}{l}\text { Phosphorous } \\
\left(\mathrm{kg} \mathrm{ha}^{-1}\right)\end{array}$} & \multicolumn{3}{|c|}{ Seed oil content (\%) } & \multicolumn{3}{|c|}{ Seed P uptake (\%) } \\
\hline & \multicolumn{2}{|c|}{ Accessions } & \multirow{2}{*}{ Mean } & \multicolumn{2}{|c|}{ Accessions } & \multirow{2}{*}{ Mean } \\
\hline & Canadian & Australian & & Canadian & Australian & \\
\hline 0 (Control) & $31.3 \mathrm{e}$ & $33.6 \mathrm{de}$ & $32.5 \mathrm{D}$ & $0.17 b$ & $0.21 \mathrm{~b}$ & $0.19 \mathrm{~B}$ \\
\hline 30 & $34.7 \mathrm{~cd}$ & $36.0 \mathrm{bcd}$ & $35.3 \mathrm{C}$ & $0.64 a$ & $0.66 \mathrm{a}$ & $0.65 \mathrm{~A}$ \\
\hline 40 & $36.9 \mathrm{abcd}$ & $37.9 \mathrm{abc}$ & $37.4 \mathrm{~B}$ & $0.62 \mathrm{a}$ & $0.69 a$ & $0.65 \mathrm{~A}$ \\
\hline 60 & $39.6 \mathrm{ab}$ & $40.1 \mathrm{a}$ & $39.8 \mathrm{~A}$ & $0.64 a$ & $0.70 \mathrm{a}$ & $0.67 \mathrm{~A}$ \\
\hline $\begin{array}{c}\text { Means of } \\
\text { accessions }\end{array}$ & $35.6 \mathrm{~A}$ & $36.9 \mathrm{~A}$ & & $0.52 \mathrm{~A}$ & $0.56 \mathrm{~A}$ & 0.05 \\
\hline HSD (0.05) & \multicolumn{2}{|c|}{2.02} & 1.84 & \multicolumn{2}{|c|}{0.06} & \\
\hline
\end{tabular}

Values in the column or means of accessions within the row sharing the same letter did not differ significantly with each other at $5 \%$ probability level. Values with capital letters are the main effect and with small letters are interactive effects. 


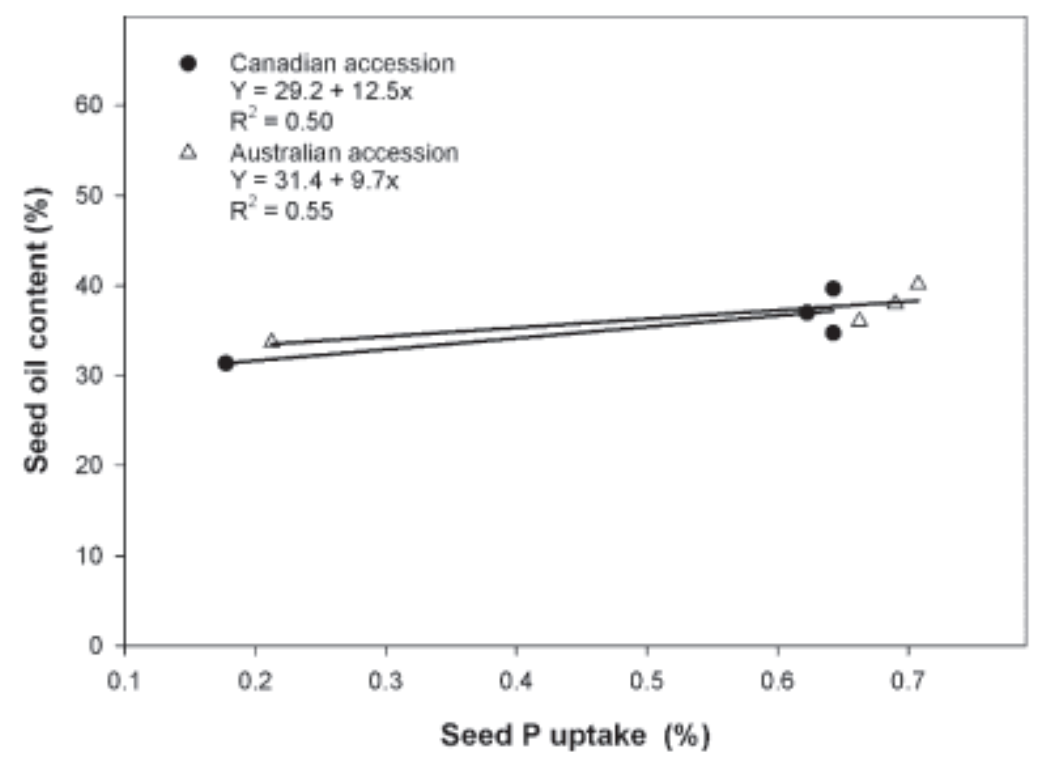

Figure 4. Relationship between seed oil content and seed $\mathrm{P}$ uptake of two Camelina sativa L. accessions as influenced by different phosphorous rates.

\section{Conclusion}

Camelina sativa L. accessions responded variably to $P$ application and Australian accession was found more responsive than Canadian accession. The increase in $\mathrm{P}$ rate from 0 to $60 \mathrm{~kg} \mathrm{ha}^{-1} \mathrm{improved}$ the growth, yield, and seed quality of $C$. sativa accessions. Thus, the study concluded that 60 $\mathrm{kg} \mathrm{P} \mathrm{ha}^{-1}$ should be applied to achieve optimum yield and profitability.

\section{References}

Ahmad, H. B., Amin, M. A., Hussian, I., Rafique, C. M., Naveed, M., Awais, M. A., Aqeel, M. (2014). Effect of different sowing dates on yield contributing traits of Mash bean (Vigna mungo L.). International Journal of Agronomy and Agriculture Research, 5(6), 42-48. Retrieved from http://citeseerx.ist. psu.edu/viewdoc/download? doi: 10.1.1.6 77.8758\&rep=rep $1 \&$ type=pdf
Ahmada, F., Uddina, S., Ahmada, N., \& Islam, R. (2013). Phosphorus-microbes interaction on growth, yield and phosphorus-use efficiency of irrigated cotton. Archives of AgronomyandSoilScience,59(3),341-351. doi: 10.1080/03650340.2011.646994

Alam, S. M., Shah, S. A., \& Akhtar, M. (2003). Varietal differences in wheat yield and phosphorus use efficiency as influenced by method of phosphorus application. Songklanakarin Journal of Science and Technology, 25(2), 175-181. Retrieved fromhttp://www.thaiscience.info/journals/ Article/SONG/10462343.pdf

Ali, A., Hussain, M., Tanveer, A., Nadeem, M. A., \& Haq, T. (2002). Effect of different levels of phosphorus on seed and oil yield of two genotypes oflinseed (Linumusitatissimum L.). Pakistan Journal of Agricultural Sciences, 39(4), 281-282. Retrieved from https://agris.fao.org/agris-search/search. do?recordID=PK2006000040 
Aziz, T., Rahmatullah, M., Maqsood, A., \& Mansoor, T. (2005). Differences in phosphorus absorption, transport and utilization by twenty rice (Oriza sativa L.) cultivars. Pakistan Journal of Agricultural Sciences, 42(2-3), 8-15.

Aziz, T., Rahmatullah, M., Maqsood, A., Tahir, M. A., Ahmad, I., \& Cheema, M. A. (2006). Phosphorus utilization by six brassica cultivars (Brassica juncea L.) from tricalcium phosphate; a relatively insoluble P compound. Pakistan Journal of Botany, 38(5), 529-538. Retrieved from http:// www.pakbs.org/pjbot/PDFs/38(5)/PJB 38(5)1529.pdf

Baghestani, M. A., Zand, E., Soufizadeh, S., Beheshtian, M., Haghighi, A., Barjasteh, A., Deihimfard, R. (2008). Study on the efficacy of weed control in wheat (Triticum aestivum L.) with tank mixtures of grass herbicides with broadleaved herbicides. Crop Protection, 27(1), 104-111. doi: 10. 1016/j.cropro.2007.04.013

Borges, R., \& Mallarino, A. P. (2001). Deep banding phosphorous and potassium fertilizers for corn managed with ridge tillage. Soil Science Society of America Journal, 65(2), 376-384. doi: 10.2136/ sssaj2001.652376x

Bugnarug, C., \& Borcean, I. (2000). A study on the effect of fertilizers on the crop and oil content of Camelina sativa L. Senior Labor - Agriculture, University of Agricultural Sciences Scedilla Veterinary Medicine Banat Timiscedilla, 32(2), 541-544.

Cheema, M. A., Malik, M. A., Hussain, A., Shah, S. H., \& Basra, S. M. A. (2001). Effects of time and rate of nitrogen and phosphorus application on the growth and the seed and oil yields of canola (Brassica napus L.).
Journal of Agronomy and Crop Science, 186(2), 103-110. doi: 10.1046/j.1439-037 X.2001.00463.x

Dash, S. (2005). Screening plant species for potential adaptation as agronomic crops in North Dakota. Master thesis, North Dakota State University, Fargo, USA.

Dobre, P., Jurcoane, S., Matei, F., Stelica, C., Farcas, N., \& Moraru, A. C. (2014). Camelina sativa as a double crop using the minimal tillage system. Romanian Biotechnological Letters, 19(2), 9190-9195.

Fageria, N. K., Baligar, V. C., Moreira, A., \& Moraes, L. A. C. (2013). Soil phosphorous influence on growth and nutrition of tropical legume cover crops in acidic soil. Communications in Soil Science and Plant Analysis, 44(22), 3340-3364. doi: 10.1080/00103624.2013.847954

Franzen, D. W., \& Cihacek, L. J. (1996). North Dakota fertilizer recommendation tables and equations based on soil test levels and yield goals, bull. SF-882. Servey, Fargo, ND: North Dakota State University of Extension.

Gill, M. A., Mansoor, S., Aziz, T., Rahmatullah, A., \& Akhtar, M. S. (2002). Differential growth response and phosphorus utilization efficiency of rice genotypes. Pakistan Journal of Agricultural Sciences, 39(2), 83-87.

Gugel, R. K., \& Falk, K. C. (2006). Agronomic and seed quality evaluation of Camelina sativa in western Canada. Canadian Journal of Plant Science, 86(4), 1047-1058. doi: 10. 4141/P04-081

Haby, V. A., Russelle, M. P., \& Skogley, E. O. (1990). Testing soils for potassium, calcium, and magnesium. Soil Testing 
and Plant Analysis, 3(1), 181-227. doi: 10.2136/sssabookser3.3ed.c8

Idris, M., Mahmood, T., \& Malik, K. A. (1989). Response of field-grown chickpea (Cicer arietinum L.) to phosphorus fertilization for yield and nitrogen fixation. Plant and Soil, 114(1), 135-138. doi: 10.1007/ BF02203091

Irshad, S., Rehman, H., Wahid, M. A., Saleem, F. M., Basra, S. M. A., \& Saeed, M. T. (2015). Influence of phosphorus application on growth, yield and oil quality of linola. Journal of Plant Nutrition, 39(6), 856-865. doi: 10.1080/01904167.2015.1088021

Kitson, R. E., \& Mellon, M. G. (1944). Colorimetric determination of phosphorus as molybdivanadophosphoric acid. Industrial \& Engineering Chemistry Analytical Edition, 16(6), 379-383. doi: 10.1021/i560130a017

Končius, D., \& Karčauskiene, D. (2010). The effect of nitrogen fertilisers, sowing time and seed rate on the productivity of Camelina sativa. Zemdirbyste, 97(4), 3746. Retrieved from http://193.219.178.8/ tomai/97(4)tomas/97_4_tomas_str4.pdf

Lickfett, T., Matthaus, B., Velasco, L., \& Mollers, C. (1999). Seed yield, oil and phytate concentration in the seeds of oilseed rape cultivars as affected by different phosphorus supply. European Journal of Agronomy, 11(3-4), 293-299. doi: 10.1016/S1161-0301(99)00038-6

Malavolta, E. (1989). Abc of fertilization. São Paulo: Agronômica Ceres.

Malhi, S. S., Johnson, E. N., Hall, L. M., May, W. E., Phelps, S., \& Nybo, B. (2014). Effect of nitrogen fertilizer application on seed yield, $\mathrm{N}$ uptake, and seed quality of
Camelina sativa. Canadian Journal of Soil Science, 94(1), 35-47. doi: 10.4141/ cjss2012-086

Malik, M. A., Saleem, M. F., Sana, M., \& Rehman, A. (2004). Suitable level of N, P and K for harvesting the maximum economic returns of sunflower. International Journal of Agriculture and Biology, 6(2), 240-242.

Manda, K. J., \& Sinha, A. C. (2003). Nutrient management effects on light interception, photosynthesis, growth, dry-matter production and yield of Indian mustard (Brassica juncea L.). Journal of Agronomy and Crop Science, 190(2), 119-129. doi: 10.1046/j.1439-037X.2003.00083.x

Mohanty, S., Paikaray, N. K., \& Rajan, Z. (2006). Availability and uptake of phosphorus from organic manures in groundnut (Arachis hypogea L.)-corn (Zea mays L.) sequence using radio tracer technique. Geoderma, 133(3-4), 225-230. doi: 10.10 16/j.geoderma.2005.07.009

Nutall, W. F., Monlin, A. P., \& Smith, L. J. T. (1992). Yield response of canola to nitrogen, phosphorus, precipitation, and temperature. Agronomy Journal, 84(5), 765-768. doi: 10.2134/agronj1992.0002 $1962008400050001 x$

Olsen, S. R., Cole, C. V., Watanabe, F. S., \& Dean, L. A. (1954). Estimation of available phosphorus in soils by extraction with sodium bicarbonate. (USDA Circ. 939). Washington, DC: US Government Printing Office.

Ramasamy, M., Srinivasan, K., \& Sankaran, N. (2000). Effect of ' $P$ ' mobilizers and different levels of phosphorous on growth and yield of CO-1 soybean. Madras Agriculture Journal, 87(10-12), 674-675. 
Rogério, F., Silva, da, T. R. B., Santos, J. I. dos, \& Poletine, J. P. (2013). Phosphorus fertilization influences grain yield and oil content in crambe. Industrial Crops and Products, 41(1), 266-268. doi: 10.1016/j. indcrop.2012.04.016

Sanusan, S., Polthanee, A., Seripong, S., Audebert, A., \& Mouret, J. C. (2009). Rates and timing of phosphorus fertilizer on growth and yield of directseeded rice in rain-fed conditions. Acta Agriculturae Scandinavica Section B-Soil and Plant Science, 59(6), 491-499. doi: 10.1080/09064710802368694

Sawan, Z. M., Hafezb, S. A., Basyony, A. E., \& Abou-El-Ela, R. A. (2007). Cootonseed, protein oil yields and oil properties as influenced by potassium fertilization and foliar application of Zinc and Phosphorus. Grasas $Y$ Aceites, 58(1), 40-48. doi: 10.3989/gya.2007.v58.i1.7

Shenoy, V.V., \& Kalagudi, G. M. (2005).Enhancing plant phosphorus use efficiency for sustainable cropping. Biotechnology Advances, 23(7-8), 501-513. doi: 10.10 16/j.biotechadv.2005.01.004

Solis, A., Vidal, I., Paulino, L., Johnson, B. L., \& Berti, M. T. (2013). Camelina seed yield response to nitrogen, sulfur, and phosphorus fertilizer in South Central Chile. Industrial Crops and Products, 44(1), 132-138. doi: 10.1016/j. indcrop.2012.11.005

Steel, R. G. D., Torrie, J. H., \& Dicky, D. (1997). Principles and Procedures of Statistics. Multiple comparison (3rd ed. pp. 178198). McGraw Hill Book Co., New York.
Urbaniak, S., Caldwell, C., Zheljazkov, V., Lada, R., \& Luan, L. (2008). The effect of cultivar and applied nitrogen on the performance of Camelina sativa L. in the Maritime Provinces of Canada. Canadian Journal of Plant Science, 88(1), 111-119. doi: 10.4141/CJPS07115

Vendrell, P. F., \& Zupancic, J. (1990). Determination of soil nitrate by transnitration of salicylic acid. Communications in Soil Science and Plant Analysis, 21(13-16), 1705-1713. doi: 10.1080/00103629009368334

Waraich, E. A., Ahmad, Z., Ahmad, R., Saifullah, \& Ashraf, M. Y. (2015). Foliar applied phosphorous enhanced growth, chlorophyll contents, gas exchange attributes and PUE in wheat (Triticum aestivum L.). Journal of Plant Nutrition, 38(12), 1929-1943. doi: 10.10 80/01904167.2015.1043377

Zohary, D., Hopf, M., \& Weiss, E. (2012). Domestication of plants in the old world: the origin and spread of domesticated plants in Southwest Asia, Europe, and the Mediterranean Basin. Oxford University Press, London.

Zubr, J. (2003). Qualitative variation of Camelina sativa seed from different locations. Industrial Crops and Products, 17(3), 161-169. doi: 10.1016/S0926-6690 (02)00091-2 